\title{
Effects of Composted Biosolids and Nitrogen on Turfgrass Establishment, Sod Properties, and Nutrient Export at Harvest
}

\author{
Ronnie W. Schnell ${ }^{1}$, Donald M. Vietor, Richard H. White, and \\ Tony L. Provin \\ Department of Soil and Crop Sciences, Texas A\&M University, College \\ Station, TX 77843-2474
}

Clyde L. Munster

Department of Biological and Agricultural Engineering, Texas A\&M University, College Station, TX 77843-2138

Additional index words. turfgrass sod, composted municipal biosolids, establishment, sod properties, nutrient export

\begin{abstract}
Incorporation of composted municipal biosolids (CMB) in low-quality soil can enhance turfgrass establishment and physical and chemical properties of turfgrass sod. The purpose of this research was to quantify $\mathrm{CMB}$ and fertilizer nitrogen (N) effects on Tifway bermudagrass [Cynodon dactylon (L.) Pers. var. dactylon $\times$ C. transvaalensis Burtt-Davey] coverage, sod properties, and nutrient export in harvested sod. The experiment was conducted under field conditions in College Station, TX, from 2005 through 2008. The $\mathrm{CMB}$ and $\mathrm{N}$ effects were evaluated through digital image analysis of percentage of turfgrass coverage, gravimetric measurements of sod wet and dry weight and water content at harvest, analyses of total phosphorus $(P)$ and total Kjeldahl $N$ in turfgrass and soil, and computations of total $P$ and $N$ export through sod. Incorporation of $0.25 \mathrm{~m}^{3}$ of $\mathrm{CMB} / \mathrm{m}^{3}$ soil and fertilizer $N$ rates of 50 or $100 \mathrm{~kg} \mathrm{~N} / \mathrm{ha} /$ application increased percentage of turfgrass cover during establishment compared with controls. At sod harvest, dry weight was less and water content was greater for CMB-amended sod than for sod grown without CMB. Analyses of total nutrients in CMB and in turfgrass and soil indicated that two sod harvests removed all of the $C M B$ sources of $N$ and $P$ incorporated or top-dressed during Tifway bermudagrass establishment and regrowth. Cycling of CMB through sod offers an opportunity for conserving CMB sources of nutrients and benefiting Tifway bermudagrass sod production and properties.
\end{abstract}

Organic amendments, including municipal and animal sources of biosolids, can be applied to improve soil physical and chemical properties and turfgrass establishment, growth, and quality (McCoy, 1998). Although the amendments contribute total and soluble nutrients and organic $\mathrm{C}$ to soil (Johnson et al., 2006a), a high $\mathrm{C}$ - to- $\mathrm{N}$ ratio of composted municipal biosolids (CMB) reportedly limited turfgrass growth rate and development of dark green color (Linde and Hepner, 2005). If the balance of $\mathrm{N}$ mineralization over immobilization rates from organic amendments is insufficient to meet turfgrass requirements, supplemental fertilizer $\mathrm{N}$ applications could be needed (Flavel and Murphy, 2006). Turfgrass coverage rates and the duration between sod harvests will depend on management of fertilizer $\mathrm{N}$ and the organic amendment rates.

In addition to beneficial effects during turfgrass production, the CMB sources of nutrients removed during sod harvest could

Received for publication 1 May 2009. Accepted for publication 6 Aug. 2009.

${ }^{1}$ To whom reprint requests should be addressed; e-mail ronschnell@tamu.edu. enhance establishment of the transplanted sod. These nutrients substitute for inorganic fertilizer applications on the transplanted sod (Johnson et al., 2006b). Yet, concentrations of soluble $\mathrm{P}$ and $\mathrm{N}$ in sod amended with $\mathrm{CMB}$ are directly related to concentrations and losses in runoff (Vietor et al., 2004a). The amount of CMB sources of nutrients exported in sod harvests needs to be evaluated in relation to inputs during production to assure that $\mathrm{N}$ and $\mathrm{P}$ are effectively managed without detrimental environmental impacts.

Previous studies of manure cycling through sod harvests indicated that up to $77 \%$ of total $\mathrm{P}$ and $47 \%$ of total $\mathrm{N}$ in surface applications were exported in a single sod harvest (2.5 cm depth) (Vietor et al., 2002). Incorporation of $\mathrm{CMB}$ within soil depths deeper than that of a single sod harvest is expected to reduce the portion of applied nutrients removed compared with topdressing. Yet, incorporation could enable less frequent application of higher, volume-based rates of CMB than those applied through topdressing. For the large, volume-based rates, the amount of CMB sources of nutrients in sod removed from a portion of the amended soil depth at harvest could be comparable to that in sod harvested after top-dressing of lesser rate of CMB. In addition, incorporation of CMB could reduce potential runoff loss of nutrients from sod during establishment and production and after transplanting to urban landscapes (Hansen et al., 2007).

The objectives of this study were to compare turfgrass coverage response and sod properties among establishment treatments with and without fertilizer $\mathrm{N}$ and incorporated $\mathrm{CMB}$ and to quantify export of CMB sources of total $\mathrm{N}$ and $\mathrm{P}$ with the sod layer at harvest.

\section{Materials and Methods}

Experimental design

First sod crop. The design comprised four replications of a randomized block design imposed under irrigated field conditions at the Texas A\&M University Turfgrass Field Laboratory, College Station, TX. Each replication was made up of three rates of inorganic fertilizer $\mathrm{N}\left(0,50\right.$, and $100 \mathrm{~kg} \cdot \mathrm{ha}^{-1} /$ application as $\mathrm{NH}_{4} \mathrm{NO}_{3}$ ). The three $\mathrm{N}$ rates were randomly assigned to plots $(3.0 \mathrm{~m} \times 4.5 \mathrm{~m})$ with and without incorporation of $\mathrm{CMB}$ during establishment of Tifway bermudagrass [Cynodon dactylon (L.) Pers. var. dactylon $\times C$. transvaalensis Burtt-Davey] in Oct. 2005. Fresh CMB [n=4; 51\% dry matter, $21.4 \mathrm{~g} \cdot \mathrm{kg}^{-1}$ total Kjeldahl nitrogen (TKN), $11.5 \mathrm{~g} \cdot \mathrm{kg}^{-1}$ total P (TP), and 6.5 $\mathrm{g} \cdot \mathrm{kg}^{-1}$ total $\mathrm{K}$ ] was spread with buckets and raked into a $5-\mathrm{cm}$ soil depth $\left(0.25 \mathrm{~m}^{3} \mathrm{CMB} /\right.$ $\mathrm{m}^{3}$ of soil; $89.6 \mathrm{Mg} \cdot \mathrm{ha}^{-1}$ ) before sprigging. The CMB is a compost product derived from yard trimmings and biosolids from the city of Austin municipal wastewater treatment facility and was collected in Sept. 2005 at the Hornsby Bend Biosolids Management Plant (Austin, TX). The Tifway plots grown without $\mathrm{CMB}$ received $30 \mathrm{~kg} \cdot \mathrm{ha}^{-1}$ of $\mathrm{P}$ [Ca $\left.\left(\mathrm{H}_{2} \mathrm{PO}_{4}\right)_{2}\right]$ and $200 \mathrm{~kg} \cdot \mathrm{ha}^{-1}$ of $\mathrm{K}(\mathrm{KCl})$ as inorganic fertilizer, which was raked into soil (Boonville fine sandy loam: fine smectitic thermic Vertic Albaqualf) before sprigging. The fertilizer $\mathrm{N}$ was applied at the specified rates in Oct. 2005 (3 weeks after sprigging) and in March, April, and May of 2006 during spring greenup $(24,27$, and 31 weeks after sprigging). Turf was mowed weekly to a $2.5-\mathrm{cm}$ height starting 5 weeks after sprigging, and clippings were returned to the soil surface. Sod harvest of treatments amended with $\mathrm{CMB}$ and fertilizer $\mathrm{N}$ was cut at a $2-\mathrm{cm}$ depth after complete turfgrass coverage of soil in May 2006. Complete turfgrass coverage of soil and sod harvest occurred 7 weeks later in July of 2006 for turfgrass established without fertilizer $\mathrm{N}(0 \mathrm{~kg} \mathrm{~N} / \mathrm{ha})$, with and without CMB. Sod harvested at the later date was cut at a $2.7-\mathrm{cm}$ depth to produce intact rolls at or near complete coverage, which allowed handling and sampling similar to sod grown with supplemental fertilizer N.

Second sod crop. During regrowth after the first sod harvest, a $0.5-\mathrm{cm}$ depth (29 $\left.\mathrm{Mg} \cdot \mathrm{ha}^{-1}\right)$ of fresh $\mathrm{CMB}(52 \%$ dry matter, $17.4 \mathrm{~g} \cdot \mathrm{kg}^{-1} \mathrm{TKN}, 3.5 \mathrm{~g} \mathrm{~kg}^{-1} \mathrm{TP}$, and 6.7 $\mathrm{g} \cdot \mathrm{kg}^{-1}$ total $\mathrm{K}$ ) was top-dressed on treatments 
amended with CMB before the first harvest in Apr. 2008. The CMB was collected in March of 2008 from the Hornsby Bend Biosolids Management Plant (Austin, TX). In addition, the three fertilizer $\mathrm{N}$ rates $(0,50$, and $100 \mathrm{~kg}$ $\mathrm{N} / \mathrm{ha}$ as $\left[\mathrm{NH}_{4}\right]_{2} \mathrm{SO}_{4}$ ) were top-dressed during April, May, and August of 2008 before the second sod harvest was initiated. The 7-week delay of the first sod harvest for treatments established without fertilizer $\mathrm{N}$ precluded comparisons of turfgrass regrowth and coverage among fertilizer $\mathrm{N}$ rates with and without compost. The sod harvest $(2.2 \mathrm{~cm}$ depth) was removed after complete coverage from regrowth was achieved in June of 2008 on three replications of all six treatments, including those without fertilizer N.

\section{Quantifying percentage of turfgrass coverage during establishment}

Digital image analysis was used to measure the percentage of coverage of turfgrass starting 2 weeks after sprigging. A free download of ImageJ (National Institute of Health, USA http://rsbweb.nih.gov/ij/download.html) software with a "threshold color" plug-in was used for analysis of digital photographs of turfgrass coverage in lieu of commercial software described previously (Richardson et al., 2001). A 2.0-megapixel camera (Coolpix 2500; Nikon, Melville, NY) was used to photograph plots during full sunlight at a $2 \mathrm{~m}$ height throughout the establishment period. During ImageJ analysis of the digital photographs, the threshold color plug-in enabled isolation of the green or turfgrass portion of the plot. Specific range settings included a hue range of 30 to 125 , saturation of 0 to 100 , and brightness of 0 to 100 . The threshold box was checked. The image was converted to 8-bit and the threshold (0-250) was adjusted to capture the entire "turf portion" of the image. The turfgrass area within plots was converted into red pixels and all other portions of the image were converted into white pixels. The "analyze particles" command was used to quantify the proportion of red pixels, or turfgrass, in the selected area. The number of red pixels was divided by the total number of pixels in the image. To calibrate ImageJ software, commercially available sod squares $(45-\mathrm{cm} \times 45-\mathrm{cm})$ were placed on a plot $(90-\mathrm{cm} \times 180-\mathrm{cm})$ of bare soil to represent between $0 \%$ and $100 \%$ turfgrass coverage. A regression relationship between variation of known areas of Tifway bermudagrass and variation of Image J estimates of turfgrass area in photographs of the plot provided a calibration curve (Fig. 1).

\section{Sample analysis}

Soil and CMB were sampled $(n=4)$ for analysis of TKN and TP concentrations before treatments were imposed on field plots and turfgrass was sprigged. The CMB volumes were weighed before incorporation to quantify rates of applied CMB and nutrients. For each sod harvest, a cup-cutter (10 cm diameter) was used to sample $235 \mathrm{~cm}^{2}$ of the cut sod layer, and fresh weights were determined. After weighing plugs were removed with the cup- cutter, soil was washed from turfgrass in distilled water. Turfgrass and the soil combined with wash solution were dried (for $48 \mathrm{~h}$ at $60{ }^{\circ} \mathrm{C}$ ), weighed, ground, and analyzed separately. The weight of the dried soil was combined with the weight of dried turfgrass and was subtracted from fresh plug weights to determine the dry weight and gravimetric water content of sod. TP and TKN concentrations in turfgrass and soil were analyzed by Texas Agrilife Extension's Soil, Water, and Forage Testing Laboratory. Turfgrass, CMB, and soil samples were digested as described previously (Parkinson and Allen, 1975). Concentrations of TKN in the digests were measured colorimetrically (Dorich and Nelson, 1983, Isaac and Jones, 1970). Inductively coupled plasma optical emission spectroscopy (ICP) was used to measure total $\mathrm{P}$ in the digests.

Total $\mathrm{P}$ and TKN concentrations and dry weights of soil and turfgrass separated from plug samples were used to compute total $\mathrm{N}$ and $\mathrm{P}$ export through sod for each sod harvest. In addition, total $\mathrm{N}$ and $\mathrm{P}$ amounts exported in sod without $\mathrm{CMB}$ were subtracted from amounts exported in CMBamended treatments to compute ratios of exported to applied $\mathrm{CMB}$ sources of $\mathrm{N}$ or $\mathrm{P}$ for each fertilizer $\mathrm{N}$ rate.

The General Linear Model (univariate) procedure in SPSS 13.0 (SPSS Inc., Chicago, IL) was used for analysis of variance (ANOVA) and mean separation among treatments $(P=0.05)$. The ANOVA was used to evaluate effects of varied combinations of $\mathrm{N}$ rate with and without composted $\mathrm{CMB}$ on turfgrass coverage rates during establishment and total $\mathrm{N}$ and $\mathrm{P}$ export in sod for each harvest. A T-test was used to compare means of sod physical properties between CMBamended and unamended soils. Nutrient export and sod properties were analyzed for two sod harvests, but data from the first harvest only are presented to enable comparisons to variation of turfgrass coverage among fertilizer $\mathrm{N}$ rates with and without $\mathrm{CMB}$.

\section{Results and Discussion}

Turf establishment. Before the first fertilizer $\mathrm{N}$ application, 2 weeks after sprigging, turfgrass coverage was $64 \%$ greater $(P=$ 0.001 ) for soils with than without CMB (Table
1). The greater coverage with $\mathrm{CMB}$ was attributed, in part, to greater sprig survival. Greater water retention in CMB-amended soil could have reduced desiccation of sprigs between irrigations and rain events compared with soil without $\mathrm{CMB}$. In addition, mineralization of $\mathrm{CMB}$ sources of $\mathrm{N}$ may have contributed to turfgrass growth and coverage.

Before winter dormancy ( 8 weeks after sprigging) and during spring green-up (27 weeks after sprigging), percentage of coverage was greater $(P=0.001)$ with than without $\mathrm{CMB}$ for the respective fertilizer $\mathrm{N}$ rates applied 3 and 24 weeks after sprigging (Table $1)$. In addition, percentage of coverage was greater for treatments with fertilizer $\mathrm{N}$ rates of 50 or $100 \mathrm{~kg} \cdot \mathrm{ha}^{-1}$ than without fertilizer N $(P=0.001)$, with or without CMB at 8 weeks. At 27 weeks, fertilizer $\mathrm{N}$ increased coverage for treatments without $\mathrm{CMB}$, but coverage was similar among fertilizer $\mathrm{N}$ rates for treatments with CMB (Table 1). Percentage of coverage did not differ between the high $(100 \mathrm{~kg} / \mathrm{ha})$ and moderate $(50 \mathrm{~kg} / \mathrm{ha})$ rates of fertilizer $\mathrm{N}$ after applications at 3 and 24 weeks after sprigging. For the sampling date 31 weeks after planting, after three fertilizer $\mathrm{N}$ topdressings, turfgrass coverage was greater $(P=0.001)$ for treatments with than without $\mathrm{CMB}$ at 0 fertilizer $\mathrm{N}$. In addition, coverage was greater for treatments with fertilizer $\mathrm{N}$ for Tifway established with or without incorporation of CMB (Table 1).

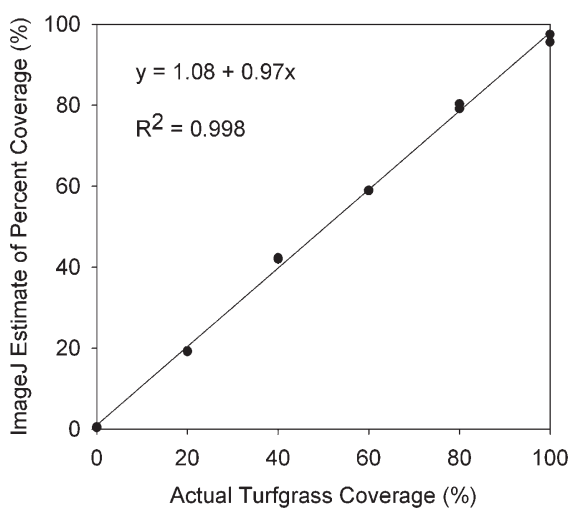

Fig. 1. Relationship between actual Tifway bermudagrass area applied as sod squares to bare soil of plot and area estimated from ImageJ analysis of digital photographs.

Table 1. Percentage of coverage of Tifway bermudagrass after sprigging (Oct. 2005) in soil with or without incorporation of $0.25 \mathrm{~m}^{3} \cdot \mathrm{m}^{-3}$ of composted municipal biosolids (CMB) and topdressing of fertilizer $\mathrm{N}(0,50$, and $100 \mathrm{~kg} \mathrm{~N} /$ ha/application) on four dates $(3,24,27$, and 31 weeks after sprigging).

\begin{tabular}{|c|c|c|c|c|c|c|}
\hline \multirow{3}{*}{$\begin{array}{l}\text { CMB rate } \\
\left(\mathrm{m}^{3} \cdot \mathrm{m}^{-3} \text { soil }\right)\end{array}$} & \multirow{3}{*}{$\begin{array}{l}\text { Fertilizer } \mathrm{N} \text { rate } \\
\left(\mathrm{kg} \cdot \mathrm{ha}^{-1} / \text { date }\right)\end{array}$} & \multicolumn{5}{|c|}{ Weeks after sprigging } \\
\hline & & 2 & 4 & $8^{y}$ & $27^{x}$ & 31 \\
\hline & & \multicolumn{5}{|c|}{ Percentage of turfgrass coverage on soil } \\
\hline$\overline{0}$ & 0 & $33 b^{z}$ & $36 \mathrm{~b}$ & $57 \mathrm{c}$ & $79 \mathrm{~d}$ & $89 \mathrm{c}$ \\
\hline 0 & 50 & $24 \mathrm{c}$ & $38 \mathrm{~b}$ & $66 \mathrm{bc}$ & $91 \mathrm{bc}$ & $99 a$ \\
\hline 0 & 100 & $25 \mathrm{c}$ & $36 \mathrm{~b}$ & $68 \mathrm{~b}$ & $90 \mathrm{c}$ & 99 a \\
\hline 0.25 & 0 & $42 \mathrm{a}$ & $55 \mathrm{a}$ & $70 \mathrm{~b}$ & $93 \mathrm{abc}$ & $98 \mathrm{~b}$ \\
\hline 0.25 & 50 & $46 \mathrm{a}$ & $62 \mathrm{a}$ & $80 \mathrm{a}$ & $96 \mathrm{a}$ & 99 a \\
\hline 0.25 & 100 & $47 \mathrm{a}$ & $61 \mathrm{a}$ & $82 \mathrm{a}$ & $96 \mathrm{ab}$ & $99 \mathrm{a}$ \\
\hline
\end{tabular}

${ }^{\mathrm{z} N u m b e r s}$ followed by the same letter within columns are not significantly different $(P=0.05)$.

${ }^{\mathrm{y}}$ Winter dormancy began.

${ }^{\mathrm{x}}$ Spring green-up. 
Similar to the present study, Linde and Hepner (2005) reported greater turf coverage and density for a 5 - to 7.5 -cm depth of compost incorporated to a $15-\mathrm{cm}$ soil depth than for soil without compost. Their observed turfgrass response to large, volume-based rates of compost was attributed, in part, to improvements in soil physical properties. Compared with soil without compost, soil organic $\mathrm{C}$ content was two to four times greater after incorporation of the 5- to 7.5-cm depths of compost (Linde and Hepner, 2005). In addition, incorporation of volume-based compost rates could reduce soil bulk density and increase water retention (McCoy, 1998).

The faster coverage rates observed after incorporation of $\mathrm{CMB}$ in the present study indicated that $\mathrm{CMB}$ could complement fertilizer $\mathrm{N}$ additions during turfgrass establishment. Yet, similar to a previous report (Sims, 1990), turfgrass responses to fertilizer $\mathrm{N}$ applied 3 weeks after sprigging indicated that plant-available and mineralized $\mathrm{N}$ from $\mathrm{CMB}$ were not sufficient to achieve rapid turfgrass coverage of soil (Table 1). Previous studies of composted manure cycling through turfgrass sod indicated that supplemental fertilizer $\mathrm{N}$ reduced the time between harvests to $60 \%$ of sod grown with manure only (Vietor et al., $2004 b$ ). To maximize the growth potential and quality of turf in soils improved through incorporation of $\mathrm{CMB}$, fertilizer $\mathrm{N}$ must be managed in relation to turfgrass requirements and plant-available $\mathrm{N}$ in $\mathrm{CMB}$.

Sod properties. In addition to increasing turfgrass coverage rates, incorporation of $0.25 \mathrm{~m}^{3} \cdot \mathrm{m}^{-3}$ of $\mathrm{CMB}$ reduced sod weight and increased soil water content on the first harvest date. Mean wet sod weight (WSW) of treatments with $\mathrm{CMB}$ was $19 \%$ less $(P=$ 0.001) than sod grown without CMB (Fig. 2). Similarly, mean dry sod weight (DSW) was $34 \%$ lower $(P=0.001)$ for the CMBamended sod. On the second harvest date, incorporated $\mathrm{CMB}$ remaining after the first harvest and $\mathrm{CMB}$ top-dressed $(0.5 \mathrm{~cm}$ depth) during regrowth reduced $(P=0.05)$ sod dry weight $10 \%$ compared with sod without CMB. In contrast, sod wet weight was similar with and without $\mathrm{CMB}$ for the second harvest. The reduced sod dry weights on both harvest dates

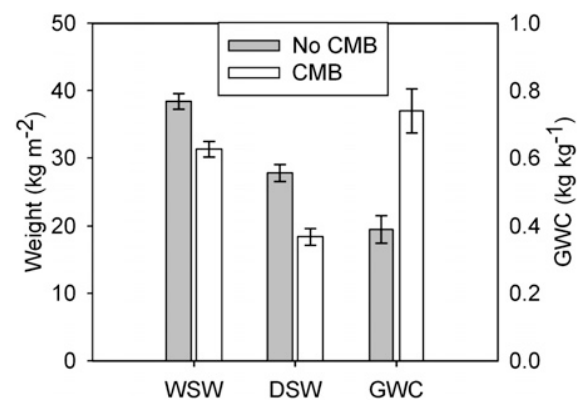

Fig. 2. Wet soil weight (WSW) and dry soil weight (DSW) and gravimetric soil water content (GWC) of sod harvested from Tifway bermudagrass established in a sandy loam soil with and without composted municipal biosolids (CMB). Error bars represent standard error of means. indicated that less native soil was removed during harvest of sod with than without CMB.

Greater $(P=0.001)$ mean gravimetric water content $(\mathrm{GWC})$ for soil with $\mathrm{CMB}$ contributed to differences in WSW for the first sod harvest (Fig. 2). Incorporation of the volume-based rate of CMB increased GWC $85 \%$. Mean GWC was similarly $39 \%$ greater $(P=0.10)$ for treatments with $\mathrm{CMB}$ for the second sod harvest. Johnson et al. (2006b) reported previously that top-dressing of composted manure at rates of 66 and $99 \mathrm{~m}^{3} \cdot \mathrm{ha}^{-1}$ increased volumetric water content in turfgrass soil compared with soil without compost. In addition, Aggelides and Londra (2000) reported compost amendments reduced soil bulk density $19.7 \%$ for a loam soil and $16.7 \%$ for a clay soil, which increased water content and retention for both soils. In addition to benefits during sod production, increases in soil water retention for sod grown with compared to without $\mathrm{CMB}$ could capture rainfall or irrigation and reduce susceptibility to drought injury after harvest and transplanting of sod.

Nitrogen export in sod harvest. Total fertilizer $\mathrm{N}$ applied to soils over four dates during turfgrass establishment without CMB ranged from 0 to $400 \mathrm{~kg} \cdot \mathrm{ha}^{-1}$. The total for fertilizer plus $\mathrm{CMB}$ sources of $\mathrm{N}$ on $\mathrm{CMB}$ amended soils ranged from 957 to 1368 $\mathrm{kg} \cdot \mathrm{ha}^{-1}$. For the initial sod harvest, greater $(P=0.01)$ concentrations and export of TKN in sod grown with compared with without $\mathrm{CMB}$ reflected the differences in TKN rate applied as CMB (Fig. 3). Concentrations of TKN in soil of the harvested sod layer ranged from 598 to $715 \mathrm{mg} \cdot \mathrm{kg}^{-1}$ for soil without $\mathrm{CMB}$ and from 4083 to $4503 \mathrm{mg} \cdot \mathrm{kg}^{-1}$ in CMB-amended soils. Although TKN export in sod (soil and turfgrass) ranged from 328 to $446 \mathrm{~kg} \cdot \mathrm{ha}^{-1}$ for sod harvested from Tifway bermudagrass established without CMB, differences among fertilizer $\mathrm{N}$ rates were not significant $(P=0.05)$ (Fig. 3). Similarly, mean export of TKN did not differ $(P=$ 0.05 ) among fertilizer $\mathrm{N}$ rates applied to sod grown with CMB. For the second sod harvest, top-dressed and incorporated CMB contributed to greater $(P=0.10)$ mean TKN export $\left(961 \mathrm{~kg} \cdot \mathrm{ha}^{-1}\right)$ than was observed in sod grown without CMB (577 kg.ha $\left.{ }^{-1}\right)$. Comparable to the first harvest, mean TKN export in the second sod harvest did not vary among fertilizer $\mathrm{N}$ rates with or without CMB.

Ratios of exported to applied total $\mathrm{N}$ up to 1.6 and 2.8 for the first and combined harvests of sod grown with inorganic fertilizer only indicated that antecedent TKN in soil contributed to estimated export of TKN. Similarly, the ratio of exported to applied TKN was 1.1 and 1.6 for the first and combined harvests of Tifway bermudagrass sod grown with $\mathrm{CMB}$ and no fertilizer $\mathrm{N}$. The TKN amounts removed in sod without $\mathrm{CMB}$ were subtracted from TKN in sod with $\mathrm{CMB}$ for respective fertilizer $\mathrm{N}$ rates to discount the antecedent soil TKN in calculations of the proportion of CMB sources of TKN exported in sod. The ratio of exported to applied TKN, exclusive of antecedent soil TKN, revealed effects of harvest depth and fertilizer $\mathrm{N}$ rate on export of CMB sources of total $\mathrm{N}$ for both sod harvests.

For the first sod harvest, the $35 \%$ greater depth of harvest for CMB-amended sod without fertilizer $\mathrm{N}$ exported a greater $(P=$ 0.05 ) proportion of the CMB source of TKN than CMB-amended sod supplemented with $100 \mathrm{~kg}$ fertilizer/N/ha/application (Fig. 4). Yet, the proportion of the CMB source of TKN exported with sod was two times greater without than with the $100-\mathrm{kg}$ rate of fertilizer $\mathrm{N}$. This difference, which was greater than could be explained by differences in harvest depth, suggested leaching or other loss of the CMB source of TKN was greater from the highest fertilizer $\mathrm{N}$ rate than sod grown with CMB alone. Similar to the lack of turfgrass coverage responses to the highest $\mathrm{N}$ rate (Table 1), increasing fertilizer $\mathrm{N}$ rates from 50 to $100 \mathrm{~kg} \mathrm{~N} /$ ha did not affect the proportion of CMB sources of TKN exported in the first sod harvest (Fig. 4).

In contrast to estimates for the initial harvest, export totaled over both sod harvests indicated that most of the CMB source of TKN within the 5-cm depth was recovered in sod for all three fertilizer N rates. Summed over harvests, $92 \%$ or more of the TKN applied in $\mathrm{CMB}$ was exported for turfgrass produced with fertilizer $\mathrm{N}$ rates of 0 and $50 \mathrm{~kg}$ N/ha/application (Fig. 5). Similar to observations for the first harvest, the increase in fertilizer $\mathrm{N}$ rate from 50 to $100 \mathrm{~kg} \cdot \mathrm{ha}^{-1} /$ application did not alter export of the $\mathrm{CMB}$

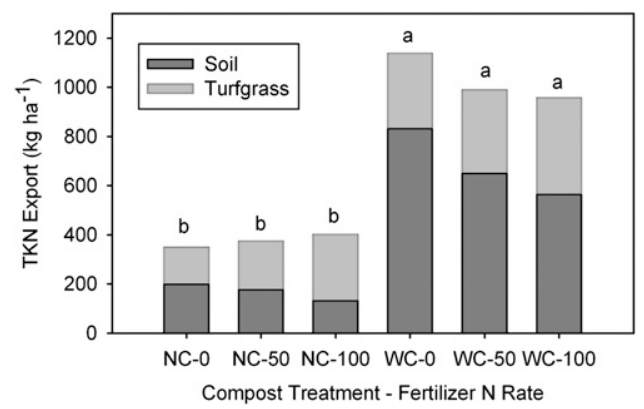

Fig. 3. The amount of total Kjeldahl N (TKN) (soil and turfgrass) removed with the initial harvest of Tifway bermudagrass sod grown with (WC) and without (NC) composted municipal biosolids (CMB) at fertilizer $\mathrm{N}$ rates of 0,50 , and $100 \mathrm{~kg} \cdot \mathrm{ha}^{-1} /$ application. Bars labeled with the same letter were not significantly different $(P=0.05)$. 
source of TKN for the combined sod harvests. Percentage of recovery of TKN from incorporated and top-dressed CMB in the two sod harvests was two times greater than that reported previously for Tifway sod harvested after two top-dressings of composted dairy manure (Vietor et al., 2002). Differences in TKN form and fate likely contributed to

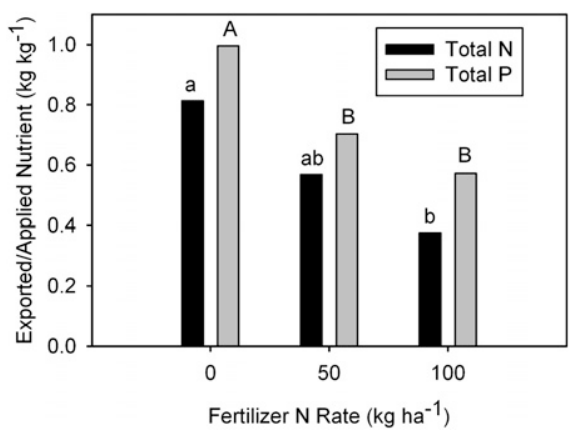

Fig. 4. The proportions of applied total Kjeldahl N (TKN) and $\mathrm{P}$ in composted municipal biosolids that was exported in the initial harvest of Tifway bermudagrass sod grown at 0,50 , and $100 \mathrm{~kg}$ fertilizer/N/ha/application. Bars labeled with the same lower case or capital letter indicate differences among fertilizer $\mathrm{N}$ rate were not statistically different $(P=0.05)$ for TKN or $\mathrm{P}$, respectively.

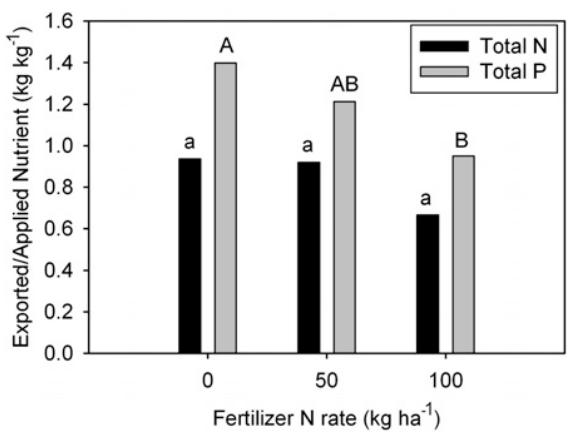

Fig. 5. The proportions of applied total Kjeldahl N (TKN) and $\mathrm{P}$ in composted municipal biosolids (CMB) that was exported in two consecutive harvests of Tifway bermudagrass sod grown at 0,50 , and $100 \mathrm{~kg}$ fertilizer/N/ha/application. Bars labeled with the same lower case or capital letter indicate differences among fertilizer $\mathrm{N}$ rate were not statistically different $(P=0.05)$ for TKN or P, respectively. variation of TKN recovery between the $\mathrm{CMB}$ and that reported previously for topdressed manure. For example, the $\mathrm{NH}_{3}-\mathrm{N}$ concentration in the dairy manure declined $94 \%$ during a $24-\mathrm{h}$ period after top-dressing on newly plugged Tifway bermudagrass (Vietor et al., 2002). Composting and incorporation of a portion of the $\mathrm{CMB}$ in the present study could have reduced $\mathrm{N}$ volatilization losses and increased recovery of CMB sources of TKN in sod compared with manure in the previous study. The present study indicated that TKN in CMB was effectively recovered in the two sod harvests cut to the depth CMB was incorporated before sprigging. Although the proportion of soil organic $\mathrm{N}$ sources recovered in Tifway plants was expected to be less than that of inorganic $\mathrm{N}$ (Barton et al., 2006), harvesting the CMB-amended soil with sod effectively removed the CMB source of TKN with turfgrass.

Phosphorus export in sod harvest. Variation of TP concentrations and export in the first sod harvest reflected the differences in TP rate applied as CMB (518 $\left.\mathrm{kg} \cdot \mathrm{ha}^{-1}\right)$ or inorganic fertilizer $\mathrm{P}\left(30 \mathrm{~kg} \cdot \mathrm{ha}^{-1}\right)$ among treatments. Mean concentrations of TP in soil of the harvested sod layer ranged from 132 to $193 \mathrm{mg} \cdot \mathrm{kg}^{-1}$ without CMB and from 2096 to $2402 \mathrm{mg} \cdot \mathrm{kg}^{-1}$ in CMB-amended soils. Similarly, mean export of TP in the first sod harvest was six times greater $(P=0.01)$ for turfgrass grown with rather than without CMB (Fig. 6). Increasing fertilizer $\mathrm{N}$ rate increased turfgrass coverage rates, but did not affect TP export in Tifway sod grown without CMB. Greater $(P=0.001)$ export of TP in sod grown with $\mathrm{CMB}$ and without fertilizer $\mathrm{N}$ was attributed to the deeper harvest depth $(2.7 \mathrm{~cm})$ compared with CMB-sod supplemented with fertilizer N. Comparable to previous observations of manure $\mathrm{P}$ export through Tifway sod (Vietor et al., 2002), supplemental fertilizer $\mathrm{N}$ did not increase TP export in turfgrass or soil $(P=0.05)$ of sod harvested from $\mathrm{CMB}$ amended sod. For the second sod harvest, mean TP export was four times greater with than without $\mathrm{CMB}(P=0.05)$, but did not vary among the fertilizer $\mathrm{N}$ rates.

For the initial sod harvest, the deeper cutting depth for Tifway grown without fertilizer $\mathrm{N}$ contributed to export of a greater proportion of the CMB source of TP than was observed for sod grown with fertilizer $\mathrm{N}$

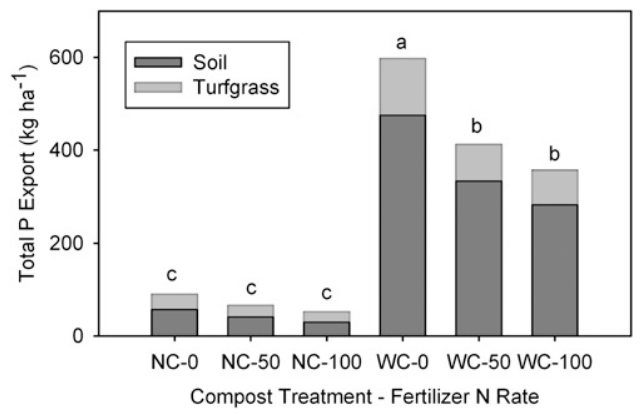

Fig. 6. Total $\mathrm{P}$ (soil and turfgrass) exported in initial harvest from Tifway bermudagrass sod grown at 0,50 , and $100 \mathrm{~kg} \cdot \mathrm{ha}^{-1} /$ application fertilizer N with (WC) and without (NC) composted municipal biosolids $(\mathrm{CMB})$. Bars labeled with the same letter were not significantly different $(P=0.05)$.
(Fig. 4). The proportions of the CMB source of TP exported in the initial sod harvest were larger than expected even though TP values of sod grown without $\mathrm{CMB}$ were subtracted from those of CMB-amended sod for the respective fertilizer $\mathrm{N}$ rates. Soil firming during cultipacking after CMB incorporation and sprigging and mowing traffic could have reduced the effective depth amended with $\mathrm{CMB}$ and increased the proportion of the CMB volume removed with sod. The proportions of the CMB source of TP exported in Tifway sod for all three $\mathrm{N}$ rates were greater than that reported previously $(0.46)$ for Tifway sod topdressed with dairy manure before harvest at a $2.5-\mathrm{cm}$ depth (Vietor et al., 2002). Similar to the present study, complete export of TP in top-dressed, composted manure was observed on a clay soil for a single harvest of Tifway bermudagrass (McDonald, 2005).

As observed for the first harvest date, the proportion of the CMB source of TP exported over both harvest dates was greater $(P=0.05)$ without fertilizer $\mathrm{N}$ than for the highest fertilizer $\mathrm{N}$ rate (Fig. 5). Values greater than one indicated antecedent soil $\mathrm{P}$, in addition to TP applied in CMB, were exported in the two sod harvests. The values greater than one occurred even though TP in soil of treatments without $\mathrm{CMB}$ was subtracted from $\mathrm{TP}$ of those amended with $\mathrm{CMB}$ for respective fertilizer $\mathrm{N}$ rates. The difference in $\mathrm{TP}$ between plots with and without $\mathrm{CMB}$ was expected to discount antecedent soil $\mathrm{P}$ from the ratio of exported to applied CMB sources of TP. Similar to the previous report of complete export of TP in CMB top-dressed on sod (McDonald, 2005), the two sod harvests in the present study removed all of the CMB source of TP incorporated and topdressed before sprigging and establishment of the Tifway bermudagrass (Fig. 5). Incorporating rather than top-dressing the large, volume-based rates of $\mathrm{CMB}$ could reduce potential runoff loss of dissolved $\mathrm{P}$ during production and after transplanting of CMBgrown sod (Hansen et al., 2007).

\section{Summary}

Incorporation of $\mathrm{CMB}$ in soil enabled the application of large, volume-based rates that reduced sod wet or dry weights and increased soil water content in Tifway bermudagrass sod harvested from the amended depths. The improvements in soil physical properties, combined with benefits of mineral nutrients in $\mathrm{CMB}$, enhanced Tifway coverage rates while conserving native soil of turfgrass sod production sites. Supplemental fertilizer N applications were necessary to achieve high Tifway coverage rates with or without $\mathrm{CMB}$, but increasing fertilizer $\mathrm{N}$ rates up to $100 \mathrm{~kg}$ $\mathrm{N} /$ ha did not affect the portion of CMB sources of TKN and TP removed in the initial and subsequent sod harvest. In addition to benefits for the initial sod harvest, the incorporated plus top-dressed CMB benefited turfgrass production until the entire depth of CMB-amended soil was removed in sod harvests. The proportion of CMB sources of 
$\mathrm{N}$ and $\mathrm{P}$ exported in a single sod harvest was less than would be expected for topdressed CMB. Yet, complete export of incorporated and topdressed $\mathrm{CMB}$ did occur, as the full depth of the amended soil layer was removed through multiple sod harvests.

\section{Literature Cited}

Aggelides, S.M. and P.A. Londra. 2000. Effects of compost produced from town wastes and sewage sludge on physical properties of a loamy and a clay soil. Bioresource Technol. 71:253-259.

Barton, L., G.G.Y. Wan, and T.D. Colmer. 2006. Turfgrass (Cynodon dactylon L.) sod production on sandy soils: I. Effects of irrigation and fertilizer regimes on growth and quality. Plant Soil 284:129-145.

Dorich, R.A. and D.W. Nelson. 1983. Direct colorometric measurement of ammonium in potassium chloride extracts of soil. Soil Sci. Soc. Amer. J. 47:833-836.

Flavel, T.C. and D.V. Murphy. 2006. Carbon and nitrogen mineralization rates after application of organic amendments to soil. J. Environ. Qual. 35:183-193.
Hansen, N.E., D.M. Vietor, C.L. Munster, R.H. White, and T.L. Provin. 2007. Runoff water quality from turfgrass receiving volume-based composted municipal biosolids applications. J. Environ. Qual. 36:1013-1020.

Isaac, R.A. and J.B. Jones, Jr. 1970. Auto-analysis for the analysis of soil and plant tissue extracts, p. 57-64. In: Advances in automated analysis. Technicon Corp., Tarrytown, NY.

Johnson, G.A., J.G. Davis, Y.L. Qian, and K.C. Doesken. 2006b. Topdressing turf with composted manure improves soil quality and protects water quality. Soil Sci. Soc. Amer. J. 70:2114-2121.

Johnson, G.A., Y.L. Qian, and J.G. Davis. 2006a Effects of compost topdressing on turf quality and growth of kentucky bluegrass. Appl. Turfgrass Sci. doi: 10.1094/ATS-2006-0113-01-RS.

Linde, D.T. and L.D. Hepner. 2005. Turfgrass seed and sod establishment on soil amended with biosolid compost. HortTechnology 15:577583.

McCoy, E.L. 1998. Sand and organic amendments influences on soil physical properties related to turf establishment. Agron. J. 90:411-419.

McDonald, B.T. 2005. The fate of manure phosphorus during production and harvest of turf- grass sod. Texas A\&M University, College Station, TX, M.S. thesis

Parkinson, J.A. and S.E. Allen. 1975. A wet oxidation procedure for determination of nitrogen and mineral nutrients in biological material. Commun. Soil Sci. Plant Anal. 6:1-11.

Richardson, M.D., D.E. Karcher, and L.C. Purcell. 2001. Quantifying turfgrass cover using digital image analysis. Crop Sci. 41:1884-1888.

Sims, J.T. 1990. Nitrogen mineralization and elemental availability in soils amended with Co-composted sewage sludge. J. Environ. Qual. 19:669-675.

Vietor, D.M., B.T. McDonald, R.H. White, T.L. Provin, and C.L. Munster. 2004b. Optimizing production and $\mathrm{P}$ export through manuregrown turfgrass sod. Agron. Abstracts, Div. C-5, No. 6401.

Vietor, D.M., E.N. Griffith, R.H. White, T.L. Provin, J.P. Muir, and J.C. Read. 2002. Export of manure phosphorus and nitrogen in turfgrass sod. J. Environ. Qual. 31:1731-1738.

Vietor, D.M., T.L. Provin, R.H. White, and C.L. Munster. 2004a. Runoff losses of phosphorus and nitrogen imported in sod or composted manure for turf establishment. J. Environ. Qual. 33:358-366. 